\title{
FUNGSI DAN WEWENANG KANTOR PERTANAHAN KABUPATEN \\ INDRAGIRI HILIR DALAM PELAKSANAAN PENDAFTARAN \\ HAK MILIK ATAS TANAH DI KECAMATAN TEMBILAHAN KABUPATEN INDRAGIRI HILIR ${ }^{1}$
}

\author{
Oleh: \\ Syariffuddin, SH.,MH dan Slamet Sutrisno, SH., MH \\ Dosen Fakultas Hukum Universitas Islam Indragiri \\ Email: ariefkhanfh6a@yahoo.com
}

\begin{abstract}
Abstrak
Pendaftaran Hak Milik atas tanah diatur didalam Undang-Undang Pokok Agraria (UUPA), khususnya Pasal 19, Kemudian dijabarkan kedalam Peraturan Pemerintah Nomor 24 Tahun 1997 tentang Pendaftaran Tanah. namun sejak diundangkannya UUPA ternyata masalah tentang pendaftaran hak milik atas tanah tidak pernah usai, begitu pula kondisinya dengan Kantor Pertanahan Kabupaten Indragiri Hilir. Sebagai pelaksana pendaftaran tanah di kabupaten, masalah pendaftaran hak milik atas tanah belum bisa diselesaikan secara baik oleh Kantor Pertanahan Kabupaten Indragiri Hilir. Kantor Pertanahan Kabupaten Indragiri Hilir dinilai kurang dalam memberikan pemahaman tentang pentingnya pendaftaran hak milik atas tanah sehingga masih banyak masyarakat yang belum mengerti tentang arti pentingnya sebuah sertipikat hak milik atas tanah.
\end{abstract}

Kata kunci: Fungsi, Wewenang, Kantor Pertanahan, Pendaftaran Hak Milik.

\section{A. Pendahuluan}

Tanah merupakan karunia Tuhan Yang Maha Esa yang harus disyukuri dan dipelihara keberadaannya. Tanah mempunyai peran yang sangat penting untuk memenuhi kebutuhan dasar bagi setiap manusia, ${ }^{2}$ yaitu sebagai tempat untuk bermukim maupun untuk melakukan kegiatannya sehari-hari. Bahkan dalam konteks yang lebih luas, salah satu unsur konstitutif terbentuknya suatu negara harus ada wilayah tertentu ${ }^{3}$ (tanah) atau lingkungan kekuasaan. ${ }^{4}$

Pada Pasal 33 ayat (3) Undang-Undang Dasar 1945 telah mengamanatkan bahwa bumi, air dan kekayaan alam yang terkandung di dalamnya dikuasai oleh Negara dan dipergunakan untuk sebesar-besarnya kemakmuran rakyat. Ketentuan yang terdapat dalam Pasal 33 ayat (3) UUD 1945 tersebut, agar dapat

${ }^{1}$ Disampaikan dalam Jurnal Litigasi Fakultas Hukum, Universitas Islam Indragiri, Riau.

${ }^{2}$ Maria S.W. Sumardjono, Kebijakan Pertanahan Antara Regulasi dan Implementasi, Buku Kompas,Jakarta, 2005, Hlm. 19.

${ }^{3}$ Moh.Kusnardi dan Harmaily Ibrahim, Pengantar Hukum Tata Negara Indonesia, Pusat Studi Hukum Tata Negara Fakultas Hukum Universitas Indonesia dan CV Sinar Bakti, Jakarta 1983, Hlm. 291.

${ }^{4}$ Samidjo,Ilmu Negara, Armico, Bandung, 1986, Hlm. 34. 
dilaksanakan, maka dijabarkan dalam suatu perangkat hukum dalam bentuk Undang-Undang yaitu Undang-Undang Nomor 5 Tahun 1960 tentang Peraturan Dasar Pokok-Pokok Agraria atau yang lebih dikenal dengan sebutan UndangUndang Pokok Agraria (selanjutnya disingkat UUPA).

Negara Indonesia kaya akan sumber daya alamnya, salah satunya adalah tanah. Dalam hukum tanah, pengertian tanah telah diberi batasan sebagaimana yang diatur dalam UUPA. Menurut Pasal 4 ayat (1) UUPA, "Atas dasar hak menguasai dari negara....adanya macam-macam hak atas permukaan bumi yang disebut tanah, yang dapat diberikan kepada dan dipunyai oleh orang-orang....", berarti dalam hal ini yang dimaksud dengan tanah adalah permukaan bumi. Tanah merupakan sumber daya alam yang dikuasai oleh negara, yang perlu dijaga kelestariannya dan dimanfaatkan untuk sebesar-besar kemakmuran rakyat, baik bagi generasi sekarang maupun bagi generasi yang akan datang. ${ }^{5}$ Hak menguasai negara, merupakan hak yang dimiliki oleh negara untuk menguasai tanah. Hak menguasai Negara atas tanah bersumber pada Hak Bangsa Indonesia atas tanah, yang hakikatnya merupakan penugasan pelaksanaan tugas kewenangan bangsa yang mengandung unsur hukum Publik. ${ }^{6}$ Adapun hak-hak atas tanah sebagaimana yang dimaksud dalam Pasal 4 ayat (1) UUPA ialah: ${ }^{7}$

1. Hak milik;

2. Hak guna-usaha;

3. Hak guna-bangunan;

4. Hak pakai;

5. Hak sewa;

6. Hak membuka tanah;

7. Hak memungut hasil-hutan;

8. Hak-hak lain yang tidak termasuk dalam hak-hak tersebut di atas yang akan ditetapkan dengan undang-undang serta hak-hak yang sifatnya sementara sebagai yang disebutkan dalam Pasal 53.

Salah satu tujuan Undang-Undang Pokok Agraria (UUPA) adalah untuk memberikan kepastian hukum berkenaan dengan hak-hak atas tanah yang dipegang oleh masyarakat. Untuk mencapai tujuan tersebut, pemerintah menyelenggarakan pendaftaran tanah, dan secara tegas diatur dalam Pasal 19 ayat (1) UUPA yang menyatakan bahwa :

"Untuk menjamin kepastian hukum oleh Pemerintah diadakan pendaftaran tanah diseluruh wilayah Republik Indonesia menurut ketentuan-ketentuan yang diatur dengan Peraturan Pemerintah”.

Apa yang telah diperintahkan oleh Pasal 19 ayat (1) UUPA tersebut, kemudian ditegaskan lebih lanjut dalam Pasal 3 Peraturan Pemerintah R.I. Nomor 24 Tahun 1997 tentang Pendaftaran Tanah.

\footnotetext{
${ }^{5}$ Boedi Harsono, Hukum Agraria Indonesia, Sejarah Pembentukan Undang-Undang Pokok Agraria, Isi dan Pelaksanaannya, Djambatan, Jakarta, 2008, Hlm. 18.

${ }^{6}$ W. Riawan Tjandra, Hukum Administrasi Negara, Universitas Atma Jaya Yogyakarta, 2008, Yogyakarta, Hlm. 107.

${ }^{7}$ Pasal16 ayat (1) UUPA.
} 
Berdasarkan ketentuan Pasal 19 UUPA dan Pasal 3 PP No. 24 Tahun 1997 diatas berlaku terhadap rumusan Hak Atas Tanah termasuk didalamnya Hak Milik. Oleh karena itu Hak Milik atas tanah perlu didaftarkan untuk memperoleh kepastian hukum terhadap Hak Milik tersebut.

Badan Pertanahan Nasional merupakan lembaga non departemen yang mempunyai bidang tugas dibidang pertanahan dengan unit kerjanya, yaitu kantor wilayah BPN ditiap-tiap Provinsi dan di daerah Kabupaten atau Kota yang melakukan pendaftaran hak atas tanah dan pemeliharaan daftar umum pendaftaran tanah.

Untuk melaksanakan pendaftaran tanah dalam rangka menjamin kepastian hukum di daerah, maka oleh BPN dibentuklah Kantor Wilayah Badan Pertanahan Nasional Provinsi di Provinsi dan Kantor Pertanahan Kabupaten/Kota di Kabupaten $/$ Kota. $^{8}$

Untuk menjamin kepastian hukum dalam pendaftaran hak milik atas tanah di Kabupaten Indragiri Hilir maka dibentuklah Kantor Pertanahan Kabupaten Indragiri Hilir. Sesuai dengan Peraturan Kepala BPN diatas, Kantor Pertanahan Kabupaten Indragiri Hilir diberi wewenang untuk menandatangani peta bidang bidang, surat ukur, buku tanah, dan sertipikat.

Dalam pelaksanaan pendaftaran hak milik atas tanah di Kabupaten Indragiri Hilir, Kantor Pertanahan Kabupaten Indragiri Hilir sering menghadapi kendala-kendala diantaranya adalah masih kurangnya pemahaman masyarakat dalam memahami arti pentingnya pendaftaran hak milik atas tanah, sehingga banyak diantaranya yang masih belum memiliki sertipikat hak milik atas tanah, Padahal dari sertpikat itulah yang dapat menjamin kepastian hukum dari kepemilikan tanahnya. Selain itu Kantor Pertanahan Kabupaten Indragiri Hilir juga menghadapi kasus kepemilikan sertipikat hak milik atas tanah ganda.

Berdasarkan data Geo KKP (Komputerisasi Kantor Pertanahan) Kantor Pertanahan Kabupaten Indragiri Hilir sampai dengan bulan Agustus 2013 terhadap bidang tanah yang telah terdaftar sesuai dengan tabel sebagai berikut :

Tabel No. 1. Kepemilikan Sertipikat Hak Milik di Kec. Tembilahan

\begin{tabular}{|c|l|l|c|}
\hline NO. & \multicolumn{1}{|c|}{ DESA/KEL } & KECAMATAN & $\begin{array}{c}\text { JUMLAH } \\
\text { SERTIPIKAT } \\
\text { HAK MILIK }\end{array}$ \\
\hline 1. & SEBERANG THB & TEMBILAHAN & 1.066 \\
2. & S. PERAK & & 947 \\
3. & TBH HILIR & & 2.120 \\
4. & TBH KOTA & & 2.832 \\
5. & PEKAN ARBA & & 1.301 \\
6. & S. BERINGIN & 2.222 \\
\hline \multicolumn{2}{|c|}{ JUMLAH } \\
\hline
\end{tabular}

Sumber data: Geo KKP Agustus 2014

Berdasarkan pengamatan Research yang peneliti lakukan, terlihat bahwa dalam penguasaan dan pemilikan hak atas tanah masyarakat Kabupaten Indragiri

${ }^{8}$ Lihat: Pasal28 ayat (1) Perpres No. 10 Tahun 2006 jo. Perpres No. 85 Tahun 2012. 
Hilir, khususnya yang ada di Kecamatan Tembilahan sampai saat ini ternyata masih banyak warga yang tanahnya belum terdaftar di Kantor Pertanahan Kabupaten Indragiri Hilir. Dari jumlah penduduk tahun 2013 adalah sebanyak 69.498 jiwa, dan Kepala Keluarga sebanyak 27799 KK ternyata yang baru memiliki sertipikat Hak Milik atas tanah hanya berjumlah 10.488.

Dengan menggunakan metode Purposive, penulis menentukan jumlah sampel berdasarkan populasi terbesar (Kelurahan Tembilahan Kota) dan terkecil (Kelurahan Sungai Perak). Dari kedua kelurahan tersebut dapat dilihat jumlah hak milik atas tanah pada tahun 2012-2013.

Tabel No. 2. Jumlah Sertipikat HM Tahun 2012/2013

\begin{tabular}{|c|l|l|c|c|c|}
\hline \multirow{2}{*}{ No } & \multirow{2}{*}{ Desa/Kelurahan } & \multirow{2}{*}{ Kecamatan } & \multicolumn{2}{|c|}{ Sertipikat Hak Milik } & \multirow{2}{*}{ Jumlah } \\
\cline { 4 - 5 } & & 2012 & 2013 & \multirow{2}{*}{ Te Bidang } \\
\cline { 4 - 5 } 1 & \multirow{2}{*}{ Tembilahan Kota } & \multirow{2}{*}{ Tembilahan } & $\begin{array}{c}56 \\
\text { Bidang }\end{array}$ & $\begin{array}{c}64 \\
\text { Bidang }\end{array}$ & \\
& & & 2 Bidang & (Nihil) & 2 Bidang \\
\hline 2 & Sungai Perak & &
\end{tabular}

Sumber Data: Kantor Pertanahan Kabupaten Indragiri Hilir Tahun 2014.

Berdasarkan tabel di atas, dapat dilihat bahwa pendaftaran hak milik atas tanah di Kecamatan Tembilahan dari tahun 2012/2013 tidak mengalami pertumbuhan bahkan cenderung mengalami penurunan. Dengan jumlah penduduk Kecamatan sebanyak 69.498 jiwa, jelas hal tersebut tidak sesuai dengan yang diharapakan.

\section{B. Rumusan Masalah}

Rumusan dalam penelitian ini sebagai berikut:

1. Bagaimana Fungsi dan Wewenang Kantor Pertanahan dalam Pelaksanaan Pendaftaran Hak Milik Atas Tanah di Kecamatan Tembilahan Kabupaten Indragiri Hilir?

2. Bagaimanakah hambatan serta upaya untuk mengatasi hambatan dalam pelaksanaan Pendaftaran Hak Milik Atas Tanah oleh Kantor Pertanahan Kabupaten Indragiri Hilir?

\section{Metode Penelitian}

Penelitian ini menggunakan penelitian observasi (observational research), ${ }^{9}$ sedangkan dilihat dari sifatnya maka penelitian ini bersifat deskriptif yang bertujuan untuk menggambarkan sesuatu yang tengah berlangung pada saat riset sedang dilakukan dan memeriksa sebab-sebab dari suatu gejala tertentu. ${ }^{10}$

Dengan metode pengambilan sampel ditentukan berdasarkan tujuan tertentu dengan melihat pada persyaratan-persyaratan antara lain: didasarkan pada ciri-ciri, sifat-sifat atau karakteristik tertentu yang merupakan ciri-ciri utama dari obyek yang diteliti dan penentuan karakteristik populasi yang

9 Soerjono Soekanto \& Sri Mamudji, Penelitian Hukum Normatif, Raja Grafindo Persada, 2004, Hlm. 13

10 Husein Umar, Metode Penelitian untuk Skripsi dan Tesis Bisnis Edisi Kedua, Rajawali Press, Jakarta, 2008, Hlm. 22 
dilakukan dengan teliti melalui studi pendahuluan. Untuk lebih jelasnya mengenai jumlah populasi dan sampel dapat dilihat dalam tabel berikut:

\begin{tabular}{|c|l|c|c|c|}
\hline \multicolumn{5}{|c}{ Tabel.1 Populasi dan Sampel Penelitian } \\
\hline No. & \multicolumn{1}{|c|}{ Objek Penelitian } & Populasi & $\begin{array}{c}\text { Sampel/ } \\
\text { Responden }\end{array}$ & Persentase \\
\hline 1 & $\begin{array}{l}\text { Kec.Tembilahan: } \\
\text { 1) Kel. Tembilahan } \\
\text { Kota;dan } \\
\text { 2) Kel. Sei Perak }\end{array}$ & 1) 2.832 & 30 & $90,9 \%$ \\
\hline 2 & $\begin{array}{l}\text { Lurah TBH Kota dan } \\
\text { Sei. Perak }\end{array}$ & 2 & 2 & $6.1 \%$ \\
\hline 3 & $\begin{array}{c}\text { Kepala Kantor } \\
\text { Pertanahan Kab. Inhil }\end{array}$ & 1 & 1 & $3,0 \%$ \\
\hline & Jumlah & $\mathbf{3 7 8 2}$ & $\mathbf{3 3}$ & $\mathbf{1 0 0 \%}$ \\
\hline
\end{tabular}

Sumber: Data Olahan Tahun 2014

\section{Pembahasan}

\section{a. Fungsi dan Wewenang Kantor Pertanahan dalam Pelaksanaan Pendaftaran Hak Milik Atas Tanah di Kecamatan Tembilahan Kabupaten Indragiri Hilir}

Berdasarkan hasil wawancara dengan Kepala Kantor Pertanahan Kabupaten Indragiri Hilir sebagai narasumber penulis, mengenai peranan Kantor Pertanahan Kabupaten Indragiri Hilir dalam upaya untuk meningkatkan pendaftaran hak milik atas tanah adalah sebagai berikut : ${ }^{11}$

1. Memberikan kegiatan penyuluhan tentang pertanahan

Dalam hal ini Kantor Pertanahan mempunyai fungsi yang sangat besar dalam upaya meningkatkan pendaftaran hak atas tanah yang dikuasai oleh masyarakat dengan mengadakan penyuluhan secara intensif untuk menumbuhkan kesadaran hukum masyarakat khususnya di bidang pertanahan.

Berdasarkan hasil penelitian penulis di daerah sampel (Kel. TBH Kota dan Sei Perak) menunjukkan, bahwa penyuluhan tersebut jarang dilakukan yang seharusnya dilaksanakan secara rutin dan efektif, tetapi dalam praktiknya masih bersifat insidental saja.

Berbeda dengan pernyataan dari salah satu aparat Kantor Pertanahan yang ada di Kabupaten Indragiri, menyebutkan bahwa

11 Hasil Wawancara dengan Bapak Ir. Z. Zahirullah (Kepala Kantor Pertanahan Kabupaten Indragiri Hilir), Tanggal 18 Desember 2014, Pukul 14.23 WIB. 
penyuluhan di bidang pertanahan dilakukan minimal satu bulan sekali dan jika terdapat permintaan dari desa yang menginginkan adanya penyuluhan tersebut diadakan di daerahnya. Memang terdapat beberapa kegiatan yang diadakan oleh Kantor Pertanahan dan kepala desa setempat seperti dalam program pensertipikatan massal sudah dilakukan, tetapi di dalam kegiatan tersebut masih dirasakan kurang memberikan adanya pemahaman di bidang pertanahan. Sehingga masih banyak masyarakat yang belum mengerti tentang arti pentingnya sebuah sertipikat, hal ini menyebabkan banyak tanah warga yang diserobot oleh pihak-pihak yang sengaja memanfaatkan kondisi seperti itu.

Berdasarkan kajian di atas ternyata pelaksanaan pendaftaran hak atas tanah yang dilakukan oleh Pemerintan dalam hal ini Kantor Pertanahan Kabupaten Indragiri Hilir, sampai saat ini masih belum tuntas dan masih memiliki banyak masalah. Oleh karena itu, dalam rangka percepatan pelaksanaan pendaftaran hak atas tanah, baik Badan Pertanahan Nasional maupun Kantor Pertanahan Kabupaten Indragiri Hilir telah menempuh berbagai kebijakan pembangunan pertanahan seperti, kegiatan Proyek Operasional Agraria (Prona), Proyek Operasional Daerah Agraria (Proda), Sertipikat Massal Swadaya (SMS) atau Pensertipikatan Swadaya Masyarakat (PSM), dan Program Pembaharuan Agraria Nasional (PPAN).

Diharapkan dengan adanya kebijakan yang dibuat oleh Kantor Pertanahan Kabupaten Indragiri diatas, tidak ada lagi hak-hak masyarakat yang dilanggar oleh karena ketidaktahuannya. Selain itu, menurut penulis bahwa setiap kebijakan tidak akan terlaksana tanpa adanya dukungan dari berbagai pihak yang terlibat didalamnya seperti Kantor Pertanahan Kabupaten Indragiri Hilir, Camat, Lurah, Kepala Desa, dan warga pemegang hak milik atas tanah itu sendiri.

2. Memberikan pelayanan administrasi di bidang pertanahan

Dalam hal ini Kantor Pertanahan Kabupaten Indragiri Hilir merumuskan lima program prioritas kerja Kantor Pertanahan Kabupaten Indragiri Hilir, dalam upaya untuk memberikan dan meningkatkan pelayanan pendaftaran hak milik atas tanah di seluruh Kabupaten Indragiri Hilir, yaitu: ${ }^{12}$

a. Membangun Kepercayaan masyarakat pada Kantor Pertanahan Kabupaten Indragiri Hilir;

b. Meningkatkan pelayanan dan pelaksanaan pendaftaran tanah;

c. Penyelesaian permasalahan dan konflik pertanahan;

d. Pengelolaan Sistem Informasi Manajemen Pertanahan;

e. Menata kelembagaan/perbaikan Infrastruktur.

Agar kebijakan pelayanan di atas dapat berfungsi dan terselenggara dengan baik, Kantor Pertanahan Kabupaten/Kota menerbitkan brosur

12 Hasil Wawancara dengan Kepala Kantor Pertanahan Kabupaten Indragiri Hilir, Tanggal 18 Desember 2014, Pukul 14.23 WIB. 
pedoman kegiatan pelayanan pertanahan. Dalam brosur tersebut diuraikan secara rinci mengenai jenis-jenis pelayanan dan persyaratannya dengan sistem loket terpadu, yaitu: ${ }^{13}$

a. Pengukuran dan Pemetaan;

b. Pendaftaran hak untuk pertama kali;

c. Pendaftaran peralihan hak;

d. Pemberian hak perorangan;

e. Penerbitan sertipikat, pemisahan dan penggabungan;

f. Pendaftaran perubahan hak;

g. Pelayanan informasi.

Berdasarkan hasil penelitian dilapangan menunjukkan bahwa kegiatan di atas tidak berjalan dengan baik, karena disebabkan kurangnya sosialisasi yang dilakukan oleh Kantor Pertanahan Kabupaten Indragiri Hilir mengenai kebijakan tersebut kepada masyarakat, sehingga stigma negatif yang terlanjur diberikan oleh masyarakat tentang buruknya pelayanan pertanahan dengan efek yang menyertainya tidak dapat dipungkiri. Hal tersebut merupakan masalah yang harus menjadi tantangan bagi semua insan pertanahan, mengingat sikap masyarakat yang semakin hari semakin kritis dalam menyikapi setiap bentuk pelayanan apapun, terutama yang berkaitan dengan pelayanan publik. Pelayanan yang memadai merupakan hak mereka dalam menuntut pertanggung jawaban publik yang mestinya diterima. Selama ini Instansi pelayanan publik lupa bahwa salah satu pencapaian guna membangun kepercayaan masyarakat (trust building) dapat diwujudkan dengan cara merebut simpati masyarakat yaitu dengan cara menyenangkan hati mereka. Apapun, bagaimanapun kondisinya, itulah tantangan yang harus dilayani dan dihadapi sebagai rutinitas yang sudah, sedang dan akan dihadapi.

Untuk merubah stigma masyarakat tentang buruknya pelayanan Kantor Pertanahan, maka Kantor Pertanahan harus melakukan reformasi birokrasi. Dengan demikian diharapkan kepercayaan masyarakat akan kembali timbul seiring berjalan waktu. Adapu bentuk pelayanan yang dapat diberikan kepada masyarakat yaitu, mulai dari bahasa verbal, bahasa tubuh, suasana ruangan, kecekatan dan kecepatan dan sebagainya, dengan hal tersebut diharapkan dapat merubah tentang stigma negatif yang sudah terlanjur diberikan oleh masyarakat terhadap buruknya pelayanan Kantor Pertanahan yang diberikan selama ini, dan untuk kedepannya diharapkan tujuan pendaftaran tanah di Kabupaten Indragiri Hilir dapat tercapai sesuai harapan Pemerintah.

Berdasarkan atas kajian di atas dapat disimpulkan bahwa tingkat kepuasan terhadap kualitas pelayanan pendaftaran tanah yang diterima oleh masyarakat, menandakan bahwa kualitas pelayanan pendaftaran tanah merupakan faktor yang berpengaruh positif terhadap kepuasan masyarakat sebagai pengguna layanan di bidang pertanahan. Adanya kesenjangan

13 Hasil Wawancara dengan Kepala Kantor Pertanahan Kabupaten Indragiri Hilir, Tanggal 18 Desember 2014, Pukul 14.23 WIB. 
antara persepsi masyarakat mengenai kualitas pelayanan pendaftaran tanah dengan kualitas pelayanan yang sebenarnya diharapkan oleh masyarakat, menyebabkan adanya perasaan puas atau tidak puas dari masyarakat. Persepsi masyarakat yang menyatakan tingkat kualitas pelayanan pendaftaran tanah buruk karena tidak sesuai dengan harapan masyarakat sehingga menyebabkan perasaan tidak puas. Namun jika persepsi masyarakat melebihi harapan yang sesungguhnya diinginkan terhadap kualitas pelayanan pendaftaran tanah berarti masyarakat merasa puas dengan pelayanan yang diberikan.

Kesimpulan dari kajian diatas mengenai peranan yang dilakukan oleh Kantor Pertanahan Kabupaten Indragiri Hilir dalam upaya untuk meningkatkan pendaftaran hak atas tanah melalui kebijakan-kebijakan diatas cukup berjalan dengan baik dan cukup mendapat sambutan yang baik dari sebagian besar masyarakat Kabupaten Indragiri Hilir, khususnya di dua Kelurahan yakni di kelurahan Tembilahan Kota dan kelurahan Sungai Perak yang menjadi sampel penelitian. Oleh karenanya menurut pendapat penulis kegiatan program pensertipikatan massal tersebut sudah sedikit membantu masyarakat dalam memperoleh alat bukti hak berupa sertipikat guna menjamin adanya kepastian hukum. Meskipun hal tersebut masih jauh dari yang diharapkan karena kebijakan diatas masih belum mampu untuk menuntaskan pendaftaran hak atas tanah secara keseluruhan yang ada di Kabupaten Indragiri Hilir. Hal tersebut tidak terlepas dari minimnya alokasi dana yang diperoleh oleh Kantor Pertanahan untuk menuntaskan program pensertipikatan massal tersebut. Untuk itu masih diperlukan adanya peran serta masyarakat untuk menuntaskan pendaftaran hak atas tanah tersebut.

\section{b. Hambatan serta upaya untuk mengatasi hambatan dalam pelaksanaan Pendaftaran Hak Milik Atas Tanah oleh Kantor Pertanahan Kabupaten Indragiri Hilir}

Sebagai langkah untuk mengetahui persentase terhadap tanggapan para pemegang hak milik atas tanah terhadap kewajiban mereka untuk mendaftarkan hak milik atas tanahnya menurut Undang-Undang Pokok Agraria, penulis melakukan penelitian di dua kelurahan Tembilahan Kota dan kelurahan Sungai Perak dengan cara memberikan kuesioner pertanyaan. Untuk kelurahan Tembilahan Kota yang menjadi responden dalam penelitian berjumlah 20 (dua puluh) responden dan untuk kelurahan Sungai Perak 10 (sepuluh) responden. Jadi secara keseluruhan yang menjadi responden dalam penelitian ini adalah berjumlah 30 orang responden yang menguasai hak atas tanah baik yang sudah bersertipikat maupun yang belum bersertipikat. Dari tabulasi yang dilakukan di dapatkan hasil sebagai berikut :

a. Umur Responden

Dari 30 orang responden berdasarkan kelas umur dalam penelitian ini yang tersebar di kecamatan Tembilahan diperoleh seperti tertera pada Tabel 5 di bawah ini. 
TABEL 5. Umur Responden

\begin{tabular}{|c|c|c|c|}
\hline NO & UMUR & JUMLAH & PERSENTASE \\
\hline 1 & $31-40$ & 7 orang & $23,3 \%$ \\
\hline 2 & $41-50$ & 15 orang & $50 \%$ \\
\hline 3 & $51-60$ & 8 orang & $26,7 \%$ \\
\hline \multicolumn{2}{|c|}{ Jumlah } & 30 orang & $100 \%$ \\
\hline
\end{tabular}

Sumber: data primer diolah tahun 2014

Berdasarkan tabel 5 di atas dapat diketahui persentase usia produktif responden dalam memahami masalah pertanahan tinggi. Dari tabel 2 di atas diketahui bahwa kelas umur responden antara 31 - 40 tahun sebesar 23, 3\%, kelas umur 41-50 tahun sebesar 50\%, dan kelas umur 51 60 tahun sebesar $26,7 \%$.

b. Pekerjaan Responden

Dari 30 orang responden berdasarkan jenis pekerjaan dalam penelitian ini yang tersebar di kecamatan Tembilahan diperoleh seperti tertera pada Tabel 6 di bawah ini.

TABEL 6. Jenis Pekerjaan Responden

\begin{tabular}{|c|c|c|c|}
\hline NO & JENIS PEKERJAAN & JUMLAH & PERSENTASE \\
\hline 1 & PNS & 15 orang & 50 \\
\hline 2 & Petani & 6 orang & 20 \\
\hline 3 & Wiraswasta & 9 orang & 30 \\
\hline & Jumlah & 30 orang & 100 \\
\hline
\end{tabular}

Sumber: data primer diolah tahun 2014

Dari tabel 6 di atas diketahui bahwa jenis pekerjaan responden seperti PNS sebesar 50\%, Petani sebesar 20\%, dan Wiraswasta sebesar $30 \%$.

c. Pendidikan Responden

Dari 30 orang responden berdasarkan tingkatan pendidikan dalam penelitian ini yang tersebar di kecamatan Tembilahan diperoleh seperti tertera pada Tabel 7 di bawah ini.

TABEL 7. Tingkatan Pendidikan Responden

\begin{tabular}{|c|c|c|c|}
\hline NO & $\begin{array}{c}\text { TINGKAT } \\
\text { PENDIDIKAN }\end{array}$ & JUMLAH & PERSENTASE \\
\hline 1 & SD & 2 orang & 6,7 \\
\hline 2 & SMP/SLTP & 5 orang & 16,7 \\
\hline 3 & SMA/SMU & 9 orang & 30 \\
\hline 4 & SARJANA & 14 orang & 46,6 \\
\hline \multicolumn{2}{|r|}{ Jumlah } & 30 orang & 100 \\
\hline
\end{tabular}

Sumber: data primer diolah tahun 2014

Sebaran tingkat pendidikan responden seperti tertera pada tabel diatas, didapatkan hasil bahwa responden yang tamat SD sebesar 6,7\%, tamat SMP/SLTP sebesar 16,7\%, tamat SMA/SMU sebesar 30\%, dan berpendidikan sarjana sebesar $46,6 \%$. Berdasarkan tabel di atas diketahui bahw presentase tertinggi adalah lulusan sarjana. Dalam hal ini tingkat 
pendidikan responden dapat memberikan gambaran tingkat pemahaman masyarakat terhadap pentingnya pendaftaran hak milik atas tanah di Kabupaten Indragiri Hilir.

Jenis pendidikan responden dihubungkan dengan tingkatan pendidikan responden dapat diketahui masih banyak responden yang belum mendaftarkan tanahnya. Diketahui hasil rekapitulasi pendaftaran hak milik atas tanah di Kantor Pertanahan Kabupaten Indragiri Hilir sebagai berikut:

Tabel No. 8. Kepemilikan Sertipikat Hak Milik di Kec. Tembilahan

Sumber data: Geo KKP Agustus 2014

\begin{tabular}{|c|l|c|c|}
\hline No. & \multicolumn{1}{|c|}{ Desa/Kel } & Kecamatan & $\begin{array}{c}\text { Jumlah } \\
\text { Sertipikat } \\
\text { Hak Milik }\end{array}$ \\
\hline 1. & Seberang Thb & Tembilahan & 1.066 \\
2. & Sei. Perak & & 947 \\
3. & Tbh Hilir & & 2.120 \\
4. & Tbh Kota & & 2.832 \\
5. & Pekan Arba & 1.301 \\
6. & Sei. Beringin & 2.222 \\
\hline \multicolumn{2}{|c|}{ Jumlah } & $\mathbf{1 0 . 4 8 8}$ \\
\hline
\end{tabular}

Dengan metode pengambilan sampel penduduk terbanyak (Kel. TBH Kota ) dan tersedikit (Kel. Sei. Perak), maka dapat dilihat perbedaanya diantara kedua kelurahan tersebut. Dengan jenis pekerjaan responden dan tingkatan pendidikan responden di Kel. TBH Kota yang bekerja di sektor pemerintahan (PNS) dan tingkatan pendidikan yang kebanyakan adalah lulusan sarjana menyebabkan kepekaan mereka terhadap pendaftaran hak milik atas tanah. Lain halnya di kelurahan Sungai Perak, dengan pekerjaan kebanyakan dari mereka adalah petani dengan pendidikan adalah lulusan SMA/SMU menyebabkan kebanyakan dari mereka belum peka terhadap pendaftaran hak milik atas tanah.

d. Cara Memperoleh Tanah

Dari 30 orang responden berdasarkan tingkatan pendidikan dalam penelitian ini yang tersebar di dua kelurahan Tembilahan Kota (20 responden) dan kelurahan Sungai Perak (10 responden) diperoleh seperti tertera pada Tabel 9 di bawah ini.

Tabel 9. Cara Memperoleh Tanah

\begin{tabular}{|c|c|c|c|}
\hline NO & Cara memperoleh Tanah & Jumlah & Persentase \\
\hline 1 & Jual beli & 19 orang & 63,3 \\
\hline 2 & Warisan & 11 orang & 36,7 \\
\hline \multicolumn{2}{|c|}{ Jumlah } & 30 orang & 100 \\
\hline
\end{tabular}

Sumber: data primer diolah tahun 2014 
Sebaran jawaban responden tentang cara perolehan tanah didapatkan hasil sebagai berikut, yaitu dengan cara membeli sebesar 63,3\% responden, dan warisan sebesar 36,7\%.

e. Jenis Alas Hak Milik Atas Tanah

Tabel 10. Alas Hak Yang Dipunyai Responden

\begin{tabular}{|c|c|c|c|}
\hline NO & Alas Hak & Jumlah & Persentase \\
\hline 1 & Sertipikat & 9 orang & 30 \\
\hline 2 & SKGR & 21 orang & 70 \\
\hline \multicolumn{2}{|c|}{ Jumlah } & 30 orang & 100 \\
\hline
\end{tabular}

Sumber: data primer diolah tahun 2014

Sebaran jawaban responden tentang alas hak milik atas tanah yang dimiliki oleh responden adalah sebagai berikut, yaitu sertipikat sebesar $30 \%$ responden, dan SKGR sebesar $70 \%$.

f. Tingkat Pengetahuan Tentang Pentingnya Sertipikat

Tabel 11. Tingkat Pengetahuan Tentang Pentingnya Sertipikat

\begin{tabular}{|c|c|c|c|}
\hline NO & Tingkat Pengetahuan & Jumlah & Persentase \\
\hline 1 & Penting & 16 orang & 53,3 \\
\hline 2 & Tidak Penting & 14 orang & 46,7 \\
\hline \multicolumn{2}{|c|}{ Jumlah } & 30 orang & 100 \\
\hline
\end{tabular}

Sumber: data primer diolah tahun 2014

Sebaran jawaban responden tentang alas hak milik atas tanah yang dimiliki oleh responden adalah sebagai berikut, yaitu yang menganggap bahwa sertipikat itu penting adalah sebesar 53,3\% responden sedangkan yang menganggap sertipikat tidak penting hanya sebesar $46,7 \%$.

g. Sumber Informasi Pendaftaran Tanah

Tabel 12. Sumber Informasi Mengenai Pendaftaran Hak Milik Atas

\begin{tabular}{|c|c|c|c|}
\hline NO & Sumber Informasi & Jumlah & Persentase \\
\hline 1 & Pemerintah & 9 orang & 30 \\
\hline 2 & Kerabat/Keluarga & 21 orang & 90 \\
\hline \multicolumn{2}{|c|}{ Jumlah } & 30 orang & 100 \\
\hline
\end{tabular}

Sumber: data primer diolah tahun 2014

Dari tabel diatas memberi indikasi bahwa di Kel. Tembilahan kota informasi yang didapat kebanyakan dari para responden tersebut adalah berasal dari pemerintah yakni sebesar 30\% dan hanya $90 \%$ yang mendapatkan informasi dari kerabat/keluarga.

h. Motivasi Pengurusan Sertipikat Hak Milik Atas Tanah

Dari 30 orang responden berdasarkan motivasi pengurusan sertipikat hak milik atas tanah yang ada di Kelurahan Tembilahan Kota dan Kelurahan Sungai Perak Kecamatan, dapat dilihat tabel berikut:

TABEL 13. Motivasi Pengurusan Sertipikat di Kel. TBH Kota

\begin{tabular}{|c|c|c|c|}
\hline NO & Motivasi & Jumlah & Persentase \\
\hline 1 & Kepastian Hukum & 4 orang & 13,3 \\
\hline 2 & Jual beli & 11 orang & 36,7 \\
\hline 3 & Jaminan & 15 orang & 50 \\
\hline \multicolumn{2}{|r|}{ Jumlah } & 30 orang & 100 \\
\hline
\end{tabular}


Sumber: data primer diolah tahun 2014

Dari tabel diatas diketahui bahwa dari 30 orang responden dalam mensertipikatkan hak atas tanahnya yaitu sebesar $13,3 \%$ responden menyatakan bahwa termotivasi untuk memperoleh kepastian hukum, $36,7 \%$ responden mengatakan bahwa termotivasi untuk kepentingan jualbeli dan 50 responden yang termotivasi karena untuk dijadikan agunan. Kondisi tersebut dapat memberikan motivasi bagi masyarakat lainnya yang belum mendaftarkan tanahnya dengan tujuan untuk dapat dijadikan sebagai agunan atau jual-beli serta adanya kepastian hukum bila disampaikan dalam penyuluhan dikemudian hari.

i. Besarnya Biaya Pendaftaran Hak Milik Atas Tanah

Tabel 14. Biaya Pendaftaran Hak Milik Atas Tanah

\begin{tabular}{|c|c|c|c|}
\hline NO & Biaya (Rp) & Jumlah & Persentase \\
\hline 1 & $550.000-692.000$ & 4 orang & 13,3 \\
\hline 2 & $692.000-950.000$ & 19 orang & 63,3 \\
\hline 3 & Diatas 950.000 & 7 orang & 23,4 \\
\hline \multicolumn{2}{|r|}{ Jumlah } & 30 orang & 100 \\
\hline
\end{tabular}

Sumber: data primer diolah tahun 2014

Dari tabel 17 di atas, dapat diketahui bahwa besarnya biaya yang dikeluarkan oleh responden untuk pendaftaran tanahnya di ketahui masing-masing antara Rp. 550.000 - Rp. 692.000 rupiah sebanyak 5 responden $=13,3 \%$, dan antara Rp. $692.000-$ Rp. 950.000 rupiah sebanyak 11 responden $=63,3 \%$, dan diatas 950.000 ribu sebanyak 8 responden $=23,4 \%$.

Contoh rincian biaya untuk tanah dengan luas di bawah $500 \mathrm{~m} 2$ meliputi : biaya pendaftaran sebesar Rp. 25.000,- biaya pengukuran sekitar Rp. 121.000,- biaya pemetaan Rp. 182.000,- biaya pemeriksaan oleh Panitia A sebesar Rp. 122.000,- untuk tanah di pedesaan dan Rp. 244.000,untuk tanah di perkotaan, serta biaya transportasi sekitar antara Rp. 20.000,- hingga Rp. 60.000,- per orang disesuaikan dengan jarak lokasi tanah. Dengan demikian total biaya yang dibutuhkan untuk tanah dengan luas di bawah $500 \mathrm{~m} 2$ antara Rp. 550.000,- hingga Rp. 692.000,-.

Berdasarkan hasil penelitian penulis di atas maka dapat diketahui yang menjadi hambatan dalam pendaftaran hak milik atas tanah di kecamatan Tembilahan adalah sebagai berikut :

1. Kurangnya Pemahaman Masyarakat

Dari hasil quisioner yang disebarkan penulis, menunjukkan kurangnya pemahaman masyarakat akan arti pentingnya pelaksanaan pendaftara peralihan hak milik atas tanah. Masih banyaknya masyarakat, khususnya pada Kelurahan Sei. Perak dalam melakukan pendaftaran hak milik atas tanahnya. Mereka beranggapan dengan dilakukannya peralihan hak atas tanah melalui jual beli yang dilakukan di bawah tangan, yang hanya bermodalkan materai, yang disaksikan oleh para pihak, jual beli tersebut dianggap sah, tanpa didaftarkannya pada Kantor Pertanahan setempat dan beranggapan bahwa pemilik tanah sudah pasti mendapatkan hak atas tanah dan jaminan kepastian hukum. 
Hal ini disebabkan masih banyaknya masyarakat Kabupaten Indragiri Hilir yang belum mengetahui secara jelas tentang pelaksanaan pendaftaran peralihan hak atas tanah di Kantor Pertanahan Kabupaten Indragiri Hilir serta syarat-syarat yang harus dipenuhi dalam pelaksanaan pendaftaran peralihan hak atas tanah karena jual beli tersebut yang tidak diketahui oleh masyarakat Kecamatan Tembilahan.

Dalam hal ini, walaupun Kantor Pertanahan telah berusaha untuk meningkatkan pendaftaran hak atas tanah, namun tidak di dukung oleh kesadaran hukum dari masyarakatnya rasanya sulit tercapai. Karena tercapai sesuatu yang diharapkan oleh pemerintah tidak terlepas dari peran serta masyarakat untuk mewujudkannya dengan mematuhi peraturanperaturan yang telah ada. Indikasinya yang terjadi dilapangan tidak sesuai dengan harapan, meskipun sebagian besar masyarakat telah mengetahui bahwa mendaftarkan hak atas tanahnya yang ia miliki merupakan kewajiban yang diharuskan oleh peraturan perundang-undangan dan hanya sebagian kecil masyarakat yang tidak mengetahuinya bahwa hak atas tanah yang dimilikinya harus didaftarkan tetapi kenyataannya mereka tidak segera mendaftarkan hak atas tanahnya.

Hal tersebut baru menunjukkan bahwa pendaftaran hak atas tanah sudah cukup memasyarakat dikalangan pemegang hak atas tanah, sekalipun dapat diperkirakan bahwa pengetahuan mereka akan keharusan mendaftarkan hak atas tanahnya itu baru merupakan pengetahuan yang masih dangkal. Begitu pula sebagian besar masyarakat tidak mendengar apalagi mengetahui diundangkannya UUPA dan Peraturan Pemerintah R.I. Nomor 24 Tahun 1997 yang mengatur tentang Pendaftaran Tanah. Begitupula mengenai syarat-syarat untuk melakukan pendaftaran hak atas tanah hanya sebagian kecil saja orang yang mengetahuinya.

2. Kurangnya Sosialisasi

Kurangnya penerangan atau penyuluhan yang diberikan kepada masyarakat. Hal tersebut, sehingga berdampak pada rendahnya inisiatif masyarakat untuk mendaftarkan hak atas tanahnya. Sosialisasi merupakan hal yang sangat penting untuk dapat lebih mendorong terhadap masyarakat khususnya pemilik hak atas tanah untuk mendaftarkan tanahnya. Dengan adanya sosialisasi dari Kantor Pertanahan, masyarakat akan menjadi mengerti akan arti pentingnya tentang manfaat kepemilikan bukti hak atas tanah berupa sertipikat. Karena kurangnya informasi maka masyarakat menganggap bahwa bukti surat kepemilikan berupa SKGR dan SKT sudah cukup dapat memberi jaminan kepastian hukum bagi hak milik atas tanahnya.

Untuk merespon rendahnya pemahaman masyarakat tentang manfaat sertipikat hak milik atas tanah, maka proses sosialisai yang intensif dapat membantu memberi pemahaman kepada masyarakat bahwa bukti surat SKGR dan SKT belumlah cukup member jaminan kepastian hukum. Oleh karena itu, perlu disertipikatkan ke Kantor Pertanahan.

3. Biaya Mahal 
Rendahnya tingkat pendaftaran hak atas tanah di Kecamatan Tembilahan disebabkan oleh beberapa hal, sebagaimana telah diuraikan pada tabel 18 yaitu meliputi :

a. Pendaftaran hak atas tanah membutuhkan biaya yang sangat mahal, hanya beberapa orang saja yang menyatakan bahwa pendaftaran hak atas tanah biayanya tidak terlalu mahal;

b. Prosedur pendaftaran hak atas tanah merupakan pekerjaan yang menjengkelkan karena berbelit-belit dan cukup merepotkan;

c. Lamanya waktu yang diperlukan untuk mengurus pendaftaran hak atas tanah berkisar antara 3-6 bulan bahkan tahunan.

Berdasarkan keterangan diatas menunjukkan bahwa sebagian besar masyarakat tidak mendaftarkan tanahnya disebabkan karena biayanya mahal. Keadaan tersebut tidak terlepas dari pekerjaan masyarakat Kecamatan Tembilahan yang sebagian besar berprofesi sebagai petani sehingga faktor biaya masih menjadi kendala untuk mengurus sertipikat hak atas tanahnya, dan hal tersebut ditambah lagi dengan adanya kecendrungan karyawan Kantor Pertanahan kehilangan idealismenya atas pengabdiannya sebagai pelayan masyarakat, sehingga banyak pegawai Kantor Pertanahan menghambat, menunda dan menghalangi penyelesaian permohonan pendaftaran hak atas tanah, atau dengan kata lain melayani dengan setengah hati atau lebih ekstrim lagi ia meminta imbalan di luar ketentuan resmi yang telah ditentukan.

Dengan berbagai permasalahan-permasalahan yang timbul dalam melaksanakan pendaftaran hak milik atas tanah yang terjadi akibat berbagai faktor, ada beberapa upaya yang dilakukan Kantor Pertanahan Kabupaten Indragiri Hilir untuk memperkecil hambatan-hambatan tersebut yang rutin dilakukan oleh pihak Kantor Pertanahan Kabupaten Indragiri Hilir.

Adapun upaya yang dapat dilakukan untuk mengatasi hambatan diatas adalah antara lain:

1. Dari segi Intern

a. Membuat pengumuman-pengumuman kepada setiap Kelurahan yang berada diwilayah Kecamatan Tembilahan Kabupaten Indragiri Hilir, tentang informasi-informasi baik mengenai pendaftaran hak milik atas tanah melalui jual beli maupun pendaftran tanah untuk pertama kalinya.

b. Selalu memanggil setiap Kepala Desa/Kepala Kelurahan untuk mendapat bimbingan dari pihak Badan Pertanahan Kabupaten Indragiri Hilir tentang pendaftaran tanah. Agar setiap kepala desa selalu melakukan peralihan hak miliknya melalui pejabat yang berwewenang demi menjamin kepastian hukumnya.

c. Memberikan pemahanan-pemahaman kepada msyarakat lewat kepala desa tentang informasi pendaftaran tanah dan besar biaya pendaftaran tanah tdak akan lari dari peraturan pemerintah yang berlaku 


\section{Dari segi Ekstern}

a. Penyuluhan langsung oleh pihak Pegawai Kantor Pertanahan Kabupaten Indragiri Hilir. Seperti yang disebutkan diatas, dimana kantor pertanahan dalam melakukan peralihan hak milik terlebih dahulu melakukan sosialisasi kepada kepala desa setempat, dan apabila perlu ada beberapa pegawai kantor pertanahan yang ikut mndampingi kepala desa untuk mensosialisasiakan mengenai pentingnya pendaftaran hak milik atas tanah. Dimana selain sudah menjadi tanggung jawab dari setiap Kepala Desa untuk kembali mensosialisasikan hal tersebut kepada warganya.

b. Dalam rangka mewadahi kesadaran hukum masyarakat mengenai kepastian pemilikan tanahnya, mulai dibentuk kelompok masyarakat sadar tertib pertanahan (Pokmasdartibnah), yang merupakan wadah partisipasi masyarakat yang melibatkan secara aktif bersamasama melakukan upaya penetapan letak dan batas-batas milik mereka termasuk menyelesaikan silang sengketa secara musyawarah dan kemudian memetakan bidang tanah milik mereka dalam satu hamparan, dengan menerbitkan sertipikat secara massal yang dibiayai secara swadaya. Pembentukan kelompok masyarakat itu pada dasarnya merupakan embrio lahirnya pendaftaran hak atas tanah yang produknya dapat dijamin kepastian pemiliknya serta diharapkan dapat memberikan perlindungan hukum bagi pemilik hak atas tanah tersebut, baik secara normatif maupun sosiologis.

Selain Usaha-usaha Dalam Mengatasi Hambatan-Hambatan di atas, Dalam Pelaksanaan Pendaftaran hak milik atas tanah di Kecamatan Tembilahan, Bahwa tidak ada suatu masalah yang tidak dapat diselesaikan, untuk itu dalam menyikapi permasalahan yang menjadi hambatan-hambatan dalam pelaksanaan pendaftaran tanah sistematik maka perlu diadakan langkah-langkah untuk mencari pemecahan yang tepat sehingga pelaksanaan pendaftaran tanah sistematik ini dapat diselesaikan dan dipecahkan permasalahannya sesuai dengan yang diharapkan oleh semua pihak.

\section{E. Kesimpulan Dan Saran}

\section{Kesimpulan}

Adapun kesimpulan yang dapat penulis paparkan dari pembahasan diatas adalah sebagai berikut:

a. Adapun fungsi kantor pertanahan adalah: 1) Menyiapkan kegiatan di bidang pengaturan penguasaan tanah, penggunaan tanah, pengurusan hakhak atas tanah, serta pengukuran dan pendaftaran hak atas tanah; 2) Melaksanakan kegiatan pelayanan di bidang pengaturan penguasaan tanah, penatagunaan tanah, pengurusan hak-hak atas tanah, pengukuran dan 
pendaftaran hak atas tanah; 3)Melakukan urusan tata usaha dan rumah tangga.

b. Berdasarkan hasil penelitian penulis di atas maka dapat diketahui yang menjadi hambatan dalam pendaftaran hak milik atas tanah di kecamatan Tembilahan adalah sebagai berikut :

1) Kurangnya Pemahaman Masyarakat

2) Kurangnya Sosialisasi

3) Biaya Mahal

4) Faktor Sarana

\section{Saran}

Saran yang dapat penulis berikan sebagai berikut:

a. Pemerintah perlu melakukan penyuluhan hukum dan sosialisasi secara intensif kepada masyarakat baik melalui media cetak maupun elektronik tentang pentingnya pendaftaran hak milik atas tanah.

b. Perlunya peningkatan anggaran biaya penyelenggaraan pensertipikatan hak atas tanah secara massal tanpa biaya atau gratis khususnya kepada masyarakat yang kurang mampu dan melakukan pembenahan terhadap peraturan yang mengatur tentang pendaftaran hak atas tanah dengan mencantumkan Pasal yang bersifat memaksa yang memberikan sanksi secara tegas kepada pemilik hak atas tanah yang tidak mendaftarkan hak atas tanahnya.

\section{DAFTAR PUSTAKA}

\section{A. Buku-Buku}

Boedi Harsono, Hukum Agraria Indonesia, Sejarah Pembentukan UndangUndang Pokok Agraria, Isi dan Pelaksanaannya, Djambatan, Jakarta, 2008;

Maria S.W. Sumardjono, Kebijakan Pertanahan Antara Regulasi dan Implementasi, Buku Kompas,Jakarta, 2005;

Moh.Kusnardi dan Harmaily Ibrahim, Pengantar Hukum Tata Negara Indonesia, Pusat Studi Hukum Tata Negara Fakultas Hukum Universitas Indonesia dan CV Sinar Bakti, Jakarta 1983;

Husein Umar, Metode Penelitian untuk Skripsi dan Tesis Bisnis Edisi Kedua, Rajawali Press, Jakarta, 2008;

Samidjo,Ilmu Negara, Armico, Bandung, 1986;

Soerjono Soekanto \& Sri Mamudji, Penelitian Hukum Normatif, Raja Grafindo Persada, 2004; 
W. Riawan Tjandra, Hukum Administrasi Negara, Universitas Atma Jaya Yogyakarta, 2008;

\section{B. Peraturan Perundang-Undangan}

Undang-Undang Dasar Negara Republik Indonesia 1945

Undang-undang Nomor 5 Tahun 1960 tentang Pokok-Pokok Agraria

Peraturan pemerintah Nomor 24 Tahun 1997 tentang Pendaftaran Tanah

\section{Wawancara}

Hasil Wawancara dengan Bapak Ir. Z. Zahirullah (Kepala Kantor Pertanahan Kabupaten Indragiri Hilir), Tanggal 18 Desember 2014, Pukul 14.23 WIB. 